Youndegin meteorite (see Simpson, E. S., Min. Mag., 25,$166 ; 1938$ ), weighing $5,789 \mathrm{lb}$; the other meteorite, which weighs $1,057 \mathrm{lb}$, has been given to the Museum by H. E. and A. G. Carlisle, and was found twenty miles from Rawlinna, on the TransAustralian Railway crossing the Nullarbor Plain. Although their exact classification has not yet been determined, both are iron-nickel meteorites (siderites).

\section{The Abbey House Museum, Leeds}

IN 1925 the Corporation of Leeds purchased the Abbey House, and under the direction of the Committee of the City Museums it has been transformed into an interesting museum. A guide, price $6 d$. , to the collections has been issued. The guide is well illustrated and clearly indicates how the objects as now arranged are illustrative of the life and work of the people of the region from the Stone Ages in general and from the twelfth century in particular. The costume display is peculiarly effective in that it is supplemented by the Eleanor Williams series of costume dolls, which on account of the accuracy of their dress portrays vividly the fashions and foibles of our ancestors.

\section{Museum of South Australia : Annual Report for 1952-53}

THE annual report for 1952-53 of the Board of the Museum of South Australia, Adelaide (pp. 12. Adelaide : Government Printer, 1954), directs attention to the fact that there has never been adequate funds to carry out field-work. This is all the more important on account of the great increase of agricultural and other activities and the consequent rapid decrease of the native fauna and flora. For example, during recent years the widespread laying from aeroplanes of baits for wild dogs has had a profound effect on the small marsupials. Notwithstanding the lack of finance, it is interesting to note that a grant of $£ A .300$ enabled a reconnaissance trip to be made to Lake Callabonna to collect specimens of Diprotodon. As a result, this important genus is now represented by additional material, including a complete adult, a juvenile skeleton less pelvis and tip of tail, and two large skulls. A detailed report on this material is awaited with interest.

\section{Training in Taxidermy}

IT is announced in the April number of the Museums Journal that arrangements have been made by the British Museum (Natural History) and the Royal Scottish Museum for training to be given in taxidermy to members of museum staffs as a preliminary to the examination for the Museum Association's Technical Certificate. Candidates, who must be on the staff of a museum, will be selected by the Education Committee and given training for a period of three months in one of the two institutions. In exceptional circumstances financial assistance may be considered. Applications should be sent to the Secretary of the Museums Association, Meteorological Buildings, Exhibition Road, London, S.W.7.

\section{Floristic Studies}

Systematic studies of the flora of tropical America by the Chicago Natural History Museum have been taken a stage further by the publication of another section of "Contributions to the Flora of Venezuela" (Fieldiana: Botany, 28, No. 3, 449-678, with line drawings, $1953 ; 4.25$ dollars). This is the work of J. A. Steyermark and collaborators and deals with the orders "Ericacea through Compositae". A floristic study of a somewhat different kind is that by H. Santapau on "The Flora of Khandala on the Western Ghats of India" (Rec. Bot. Surv. India, 16, No. 1, 1953 ; price Rs. 32 or $49 s$., from Manager of Publications, Delhi). This aims at being a complete Flora (flowering plants only), based on an intensive study of a small but interesting region situated on the western edge of the Deccan Plateau, some $116 \mathrm{~km}$. from Bombay. In an introductory essay the general features of the region are described and matters of special ecological interest discussed. "The Vegetation of Jamaica", by G. F. Asprey and R. G. Robbins (reprinted from Ecol. Monogr., 23, 359 ; 1953), is a study of plant geography and ecology of an island of special botanical interest. The general features of the island are briefly outlined, and the floristic features are then analysed and discussed under the headings of phytogeography and the varied formations and communities comprised in the flora. This monograph is illustrated by some good photographs, maps and vegetation profile diagrams. The authors conclude that the present vegetation of Jamaica enables a reasonably accurate reconstruction of the original vegetation to be made. They consider that the early descriptions of the island as being covered in dense jungles, with extensive lowland tropical rain forest, are not borne out by this survey.

\section{Discovery}

The June 1954 issue of Discovery retains the high standard which has been set by its editor, W. Iick, during the past ten years. Dr. W. E. Swinton contributes an imaginative but well-authenticated article on the possible flight mechanisms of pterodactyls which is admirably illustrated by some original line drawings. S. Rogerson links up the prehistory of Brandon in Suffolk with the 'knapping' or chipping of flint stones which is still carried on to-day, complete with a vocabulary which reveals its ancient origins. Britain's false-scorpions are the subject of an article by T. H. Savory, who describes not only their structure, habitat and behaviour but also ways of keeping and feeding them. Horticulturists should appreciate Dr. Kenneth Smith's account of the virus diseases which cause colour brealss in flowers as well as Dr. G. Haskell's description of the history and genetics of the raspberry. Another article deals with the early scientific work on platinum which was done in Spain some time before W. H. Wollaston produced malleable platinum around about 1805. The air correspondent to the journal discusses the atom bomb's effect on airplane design, while short leading articles deal with such varied topics as the future of British sociology, 'hibernation' in operating theatres, coal pumping and myxomatosis.

\section{Earthquakes during March}

Durnng March there were some thirty-four strong earthquakes in the world, ten of which had magnitude 6 or greater, and three of these latter had magnitude 71. On March 1, at 3.40 a.m. local time, an earthquake was felt over an area in Australia of some seventy thousand square miles from Kangaroo Island to Melrose, near Adelaide ; there was some property damage, but no casualties. On March 11 tremors of unknown origin were felt in Bridlington and adjacent places on the east coast of Yorkshire, which caused cracks in plaster, doubtful disturbances being observed on seismograms at the University of 